\title{
Synoviocyte-Derived Angiopoietin-Like Protein 2 Contributes to Synovial Chronic Inflammation in Rheumatoid Arthritis
}

\author{
Tatsuya Okada, ${ }^{\star \dagger}$ Hiroto Tsukano, ${ }^{\star \dagger}$ \\ Motoyoshi Endo, ${ }^{*}$ Mitsuhisa Tabata, ${ }^{*}$ \\ Keishi Miyata, ${ }^{*}$ Tsuyoshi Kadomatsu, ${ }^{*}$ \\ Kazuya Miyashita, ${ }^{\ddagger}$ Kei Semba, ${ }^{\dagger}$ \\ Eiichi Nakamura, ${ }^{\dagger}$ Michishi Tsukano, ${ }^{\S}$ \\ Hiroshi Mizuta, ${ }^{\dagger}$ and Yuichi Oike* \\ From the Departments of Molecular Genetics," Orthopaedic and \\ Neuro-Muscluloskeletal Surgery, ${ }^{\dagger}$ Graduate School of Medical \\ Sciences, Kumamoto University, Kumamoto; Immuno-Biological \\ Laboratories Co. Ltd., ${ }^{\ddagger}$ Takasaki; and the Department of \\ Orthopaedic Surgery, ${ }^{\S}$ Kumamoto Orthopaedic Hospital, \\ Kumamoto, Japan
}

Rheumatoid arthritis (RA) is a chronic inflammatory disease characterized by symmetrical polyarticular synovitis of the diarthrodial joints. Several proinflammatory cytokines derived from both infiltrating inflammatory cells and activated resident cells within the RA joint play a fundamental role in the processes that cause inflammation. However, anticytokine treatment is beneficial but not curative, the effects are only partial, and nonresponses are common. Therefore, an effort has been made to identify other key regulators of inflammation in articular structures to develop new therapies to suppress synovial inflammation and joint destruction in RA. Adipose tissuederived angiopoietin-like protein 2 (Angpt12) activates an inflammatory cascade in endothelial cells and induces chemotaxis of monocytes/macrophages in obesity, resulting in initiation and propagation of inflammation within adipose tissues and obesity-related metabolic diseases. Angpt12 mRNA and protein are abundantly expressed in hyperplastic rheumatoid synovium of RA patients, especially in fibroblast-like and macrophage-like synoviocytes, but not in $B$ and $T$ lymphocytes. Angptl2 concentration in joints of RA patients was also significantly increased in comparison with patients with osteoarthritis, which in comparison with RA represents a significantly lower inflammatory grade form of arthritis. Notably, Angptl2 promoted increased chemotactic activities of
$\mathrm{CD}_{14}{ }^{+} \mathrm{CD}^{-} 6^{-}$monocytes from synovial fluid of $\mathrm{RA}$ patients. Therefore, Angptl2 acts as an important rheumatoid synovium-derived inflammatory mediator in RA pathogenesis. (Am J Pathol 2010, 176:2309-2319; DOI: 10.2353/ajpath.2010.090865)

Rheumatoid arthritis (RA) is a chronic inflammatory disease characterized by symmetrical polyarticular synovitis of the diarthrodial joints. The RA synovial membrane contains activated B and T lymphocytes, plasma cells, mast cells, and significantly activated monocytes/macrophages. The synovium is normally a relatively acellular structure with a delicate intimal lining, thus these cells are recruited via an intense neovascularization process with associated lymphangiogenesis. Hyperplasia of the intimal lining results from macrophage-like and fibroblastlike synoviocytes. These resident and infiltrating cells within the RA joint could be a source of proinflammatory cytokines that activate inflammatory pathways in a paracrine or autocrine fashion and play a fundamental role in processes underlying inflammation, articular destruction, and comorbidities associated with RA. ${ }^{1-6}$ In fact, numerous cytokines, such as interleukin (IL)-1, IL-6, IL-15, IL18 , and tumor-necrosis factor (TNF)- $\alpha$, as well as various chemokines, are active within the synovium and synovial fluid in joints of RA patients. ${ }^{2,7,8}$ Continuous anticytokine

Supported by Grants-in-Aid for Scientific Research on Priority Areas (No.17014078) from the Ministry of Education, Culture, Sports, Science, and Technology of Japan, by Grants-in-Aid for Scientific Research (B) (No. 21390245) from the Japan Society for the Promotion of Science, by a grant from the Mochida Memorial Foundation, by a grant from the Takeda Science Foundation, by a grant from the Uehara Memorial Foundation, by a grant from the Sumitomo Foundation, and by Advanced Education Program for Integrated Clinical, Basic and Social Medicine, Graduate School of Medical Sciences, Kumamoto University (Program for Enhancing Systematic Education in Graduate Schools, MEXT, Japan).

T.O. and H.T. contributed equally to this study.

Accepted for publication January 5, 2010.

Address reprint requests to Yuichi Oike, M.D., Ph.D., Department of Molecular Genetics, Kumamoto University, 1-1-1 Honjo, Kumamoto 8608556, Japan. E-mail: oike@gpo.kumamoto-u.ac.jp. 
treatment, such as through use of TNF- $\alpha$ and IL- $1 \beta$ inhibitors, is required for long-term control, and discontinuation of treatment leads to disease flare-up, indicating the importance of cytokine-related inflammation in pathogenesis of RA. ${ }^{2}$ Furthermore, although such anticytokine treatment is beneficial, ${ }^{9-14}$ it is not curative, its effects are partial, and nonresponses are common. ${ }^{2,15}$ These findings indicate that the mechanism of inflammation in the RA joint is more complex than previously thought, thus suggesting that new factors and mechanisms are operating that could serve as novel therapeutic targets for RA.

The Angptl (Angiopoietin-like protein) family was identified as a group of proteins possessing structural similarity to angiopoietin, which contains an N-terminal coiled-coil domain functioning in oligomerization and a C-terminal fibrinogen-like domain serving as a receptor binding site. ${ }^{16,17}$ Although Angptls were predicted to function as ligands for the angiopoietin-receptor; Tie-2 or its family member; Tie-1, they do not bind to either, strongly suggesting biological functions different from those of angiopoietins. More recently, we reported that Angptl2, a member of the Angptl family, is expressed in a variety of tissues, especially in obese adipose tissues. ${ }^{18}$ Angptl2 expression has been shown to increase by hypoxia and endoplasmic reticulum stress, both of which are commonly observed in pathological conditions. We also showed that Angptl2 signaling via integrins activated an inflammatory cascade in endothelial cells and induced chemotaxis of monocytes/macrophages. Constitutive Angptl2 activation in vivo induced inflammation of the vasculature characterized by abundant attachment of leukocytes to vessel walls and increased permeability. These findings suggest that adipocyte-derived Angptl2 acts as a key chronic inflammatory mediator in obesity, resulting in obesity-related metabolic diseases. These findings, plus the fact that its expression is not restricted to adipose tissues, suggest a possible role of Angptl2 in other chronic inflammatory diseases.

The current study showed that Angptl2 mRNA and protein are abundantly expressed in the hyperplastic synoviocytes from RA patients. An in vitro culture analysis revealed that the synoviocytes from RA patients secrete Angptl2. Indeed, the concentration of Angptl2 in RA synovial fluid is significantly higher than that seen in osteoarthritis $(O A)$, which is a lower inflammatory grade arthritis than RA. Angptl2 increases the chemotactic activities of monocytes from RA synovial fluid. Taken together, these findings establish Angptl2 as a hyperplastic rheumatoid synoviumderived inflammatory mediator in RA joints.

\section{Materials and Methods}

\section{Patients and Samples}

All subjects in this study were Japanese patients who had been hospitalized at Kumamoto University Hospital and Kumamoto Orthopaedic Hospital. The subjects were selected between August 2008 and November 2009. Synovial tissues, serum, and synovial fluid were harvested for tissue analysis from 14 RA patients diagnosed according
Table 1. Clinical Features of RA and OA Patients Evaluated in the Present Study

\begin{tabular}{lcc}
\hline \multicolumn{1}{c}{ Diagnosis } & RA & OA \\
\hline Total number of subjects & 14 & 11 \\
Radiographic grading & & \\
I & 0 & 0 \\
II & 0 & 3 \\
III & 7 & 8 \\
IV & 7 & $74.9 \pm 1.9$ \\
Age, y & $63.9 \pm 3^{* *}$ & $2: 9$ \\
Male:female & $0: 14$ & n.d. \\
DAS28 ESR & $4.39 \pm 1.12$ & n.d. \\
RF, units/ml & $169.6 \pm 61.9$ & $25.2 \pm 0.7$ \\
BMI, $\mathrm{kg} \cdot \mathrm{m}^{-2}$ & $22.9 \pm 0.56^{*}$ & 25.0 \\
\hline
\end{tabular}

Radiographic grade was evaluated by using Steinbrocker Grading System for RA patients, Kellgren \& Lawrence Grading System for OA patients. RA indicates rheumatoid arthritis; OA, osteoarthritis; RF rheumatoid factor; BMI, body mass index; DAS28, disease activity score n.d., not done. ${ }^{*} P<0.05$ and ${ }^{* *} P<0.01$ in comparison with $\mathrm{OA}$ patients.

to the revised 1987 criteria of the American Rheumatism Association (ARA) ${ }^{19}$ and 11 OA patients diagnosed by clinical and radiological criteria ${ }^{20}$ who had undergone knee joint replacement surgery. Synovial tissues were fixed by perfusion with $4 \%$ paraformaldehyde phosphate buffer solution (Wako Pure Chemical Industries, Ltd., Osaka, Japan) for 1 day. Tissues were dehydrated through an ascending series of ethanols and paraffin-embedded for histology. Serum and synovial fluid were centrifuged and supernatants collected for an enzyme-linked immunosorbent assay (ELISA). Statistics relevant to the patients is shown in Table 1. Another 206 RA patients (182 females and 24 males, mean \pm SD age $59.22 \pm 13.29$ ) were analyzed to evaluate the relationship between serum Angptl2 concentrations and RA disease activity. All of these patients were also diagnosed according to the revised 1987 criteria of the ARA, ${ }^{19}$ and most patients were receiving nonsteroidal anti-inflammatory drugs (NSAIDs), prednisolone, and disease-modifying antirheumatic drugs or anticytokine biological reagents. The clinical parameters in this group were: tender joint count $1.24 \pm 1.73$, swollen joint count $4.01 \pm$ 4.10, erythrocyte sedimentation rate (ESR) $29.93 \pm 21.21$ $\mathrm{mm} / \mathrm{hour}$, and serum C-reactive protein (CRP) $0.77 \pm 1.69$ $\mathrm{mg} / \mathrm{dl}$. Serum specimens were collected from all patients for an ELISA, and each disease activity was evaluated by calculating both the disease activity score 28 (DAS28)-ESR and DAS28-CRP. A total of 84 volunteers who took no medication and were not obese (body mass index <25) were enrolled in this study as the healthy control group. The study was approved by the Ethics Committees of Kumamoto University and Kumamoto Orthopaedic Hospital. Written informed consent was obtained from all patients and healthy volunteers.

\section{Measurement of Angptl2 and Angpt/4 Concentrations in Serum, Synovial Fluid, and Culture Medium}

Angptl2 concentrations in serum, synovial fluid, and supernatants of culture medium of RA synovial fibroblast 
primary cultures were measured using the human Angptl2 ELISA as previously reported..$^{18}$ In brief, the K2-1A1 mouse monoclonal antibody was fixed to 96-well plates. Each sample was diluted 10-fold in PBS and immobilized on the plates at $37^{\circ} \mathrm{C}$ for 1 hour, followed by washing with PBS containing $0.05 \%$ Tween-20 (PBST) and addition of horseradish peroxidase-conjugated K1-12A4 mouse monoclonal antibody. The plates were incubated for 1 hour at $4^{\circ} \mathrm{C}$, then washed with PBST, and tetramethylbenzidine detection reagent was added to the wells. Thirty minutes later, the reaction was stopped by the addition of an equal amount of $1 \mathrm{~N} \mathrm{H}_{2} \mathrm{SO}_{4}$, and the absorbance was measured at $450 \mathrm{~nm}$. Both K2-1A1 and K1-12A4 antibodies were confirmed to recognize only Angptl2, and not to react to other Angptls and angiopoietins. Angpt/4 concentrations in serum and synovial fluid were measured using the human full-length form of Angptl4 ELISA kit (IBL, Japan). In brief, the K3-6A1A mouse monoclonal antibody for reacting $\mathrm{C}$ terminus of Angpt/4 was fixed to 96-well plates. Each sample was diluted 10-fold in PBS and immobilized on the plates at $37^{\circ} \mathrm{C}$ for 1 hour, followed by washing with PBST and addition of horseradish peroxidase-conjugated K2-19A1A mouse monoclonal antibody that recognized the $\mathrm{N}$ terminus of Angpt/4. The plates were incubated 1 hour at $4^{\circ} \mathrm{C}$, washed with PBST, and tetramethylbenzidine detection reagent was added to the wells. Thirty minutes later, the reaction was stopped by addition of an equal amount of $1 \mathrm{~N} \mathrm{H}_{2} \mathrm{SO}_{4}$, and the absorbance was measured at $450 \mathrm{~nm}$.

\section{In Situ Hybridization}

Digoxigenin (DIG)-UTP-labeled RNA probes were synthesized by transcription from a linearized pBluescript plasmid including full length human Angptl2 cDNA using T3 or T7 RNA polymerase and a DIG RNA labeling Mix (Roche Diagnostics, Basel, Switzerland). The concentration of the synthesized RNAs was quantified spectrometrically and confirmed by electrophoresis. Paraffin-embedded RA synovial tissues were cut into 6- $\mu \mathrm{m}$-thick sections and mounted on APS-coated slides (Matsunami Glass Ind., Ltd., Kishiwada, Japan). All procedures including deparaffinization, fixation, washing, acid treatment, protease digestion, hybridization, reaction with biotin-labeled anti-DIG antibody, reaction with alkaline phosphatase-conjugated streptavidin, and reaction with an alkaline phosphatase substrate were automatically performed using a VENTANA in situ hybridization machine (Ventana Medical Systems, Tuscon, AZ). The sections were hybridized at $65^{\circ} \mathrm{C}$ for 6 hours. DIG-labeled antisense or sense hAngptl2 probes (50 ng/slide) were denatured immediately before use. The sections were counterstained with Nuclear Fast Red for microscopic examinations.

\section{Immunohistological Study}

Paraffin-embedded tissue specimens were cut into $5-\mu \mathrm{m}$-thick sections, air-dried, and deparaffinized. Sections were autoclaved with Target Retrieval Solution
(Dako Inc.) for antigen retrieval. For performing single immunohistochemistry of Angptl2, the sections were pretreated with periodic acid (Nichirei, Tokyo, Japan) to inhibit endogenous peroxidases. The specimens were incubated with 100-fold diluted K2-1A1 mouse monoclonal anti-human Angptl2 antibody or anti-MAC2 (100-fold diluted; Santa Cruz Biotechnology Inc., CA) or anti-CD31 (Dako Inc., Carpinteria, CA) and then washed with PBS. The sections were incubated with 500-fold diluted goatanti-mouse $\operatorname{Ig}\left[\mathrm{F}\left(\mathrm{ab} \mathrm{b}^{\prime}\right) 2\right]$ conjugated with peroxidase (Amersham Pharmatech Biotech, Piscataway, NJ) as a second antibody. The peroxidase activity was visualized by incubation with a 3,3'-diaminobenzidine solution and then analyzed by light microscopy. Antibodies for synoviolin (100-fold diluted; Santa Cruz Biotechnology Inc., CA) and MAC2 (100-fold diluted; Santa Cruz Biotechnology Inc.) were used for double immunofluorescent staining of Angptl2 and other cell lineage markers. The rabbit polyclonal anti-human Angptl2 antibody, which was produced by immunizing rabbits with a synthetic peptide corresponding to amino acids 383 to 400 of human Angptl2 (SFRLEPESEYYKLRLGRY) was used for double immunofluorescent staining with CD3 (twofold diluted; Nichirei, Tokyo, Japan), CD20 (50-fold diluted; Dako Inc.), CD68 (50-fold diluted; Dako Inc.), and vimentin (100-fold diluted; Dako Inc.). After washing with PBS, sections were incubated with Alexa Fluor 488-labeled anti-rabbit lgG and Alexa Fluor 594-labeled anti-mouse IgG (Molecular Probes Inc., Eugene, OR) as second antibodies. After washing with PBS, fluorescent images were captured by confocal laser scanning microscopy (FV-300BX, Tokyo, Olympus).

\section{Primary Culture of Human Synovial Tissue-Derived Synovial Cells}

Synovial tissue specimens were obtained from five patients with RA at the time of knee joint replacement surgery. Subsequently, synovial tissues were cultured in DMEM containing $1 \%$ penicillin, $1 \%$ streptomycin, and $10 \%$ fetal canine serum as described elsewhere. ${ }^{21}$ The surviving adherent cells in these culture conditions were synovial cells, which were used to analyze the expression and secretion of Angptl2 from the third to the fifth passages.

\section{Real-Time Quantitative RT-PCR Analysis}

Total RNA was isolated with TRIzol reagent (Invitrogen, Carlsbad, CA). DNase-treated RNA was reverse transcribed with PrimeScript RT reagent Kit (Takara Bio, Ozu, Japan). Expression levels of PCR products were analyzed by Thermal Cycler Dice Real Time system (Takara Bio). Relative transcript abundance was normalized to expression of $\beta$-actin mRNA. Oligonucleotides used for PCR were: human Angptl2: forward, 5'-GCCACCAAGTGTCAGCCTCA-3', reverse, 5'-TGGACAGTACCAAACATCCAACATC-3'; human angiopoietin-1: forward, 5'-CTTCAACATCTGGAACATGTGATGG-3', reverse, 5' -TGGTTCTGAACTGCATTCTGCTG-3'; human angiopoietin-2: 
forward, 5'-GGAAATGAGTTTGTTTCGCAACTG-3', reverse, 5'-CTGGTTGGCTGATGCTGCTTA-3'; human Angpt11: forward, 5'-TTATCCCAGAGATTTAATGCCACCA3', reverse, 5'-TTTGCTTGCTGACAGTCTTTGAATG-3'; human Angpt|3: forward, 5'-TTCCAAGCCAAGAGCACCAAG-3', reverse, 5'-AAACTTGAGAGTTGCTGGGTCTGAT-3'; human Angptl4: forward, 5'-GACCTCCGCAGGGACAAGAA-3', reverse, 5'-TACTGGCCGTTGAGGTTGGAA-3'; human Angptl5: forward, AATGCACTTAGGACGGTATTCAGGA-3', reverse, 5'-ACCATTGACCAGGCATGCAG-3'; human Angptl6: forward, 5'-TCACCCAGCAGAGCAGTCTCA-3', reverse, 5'-CATCCTACTGGTGTCACTGGTGCTA-3'; human Angpt17: forward, 5'-AGCCTTCAGCACCAAGGACAA-3', reverse, 5'-TGCTCACCCAGGCGGTAGTA-3'; human b-actin: forward, 5'-TGGCACCCAGCACAATGAA-3', reverse, CTAAGTCATAGTCCGCCTAGAAGCA-3'.

\section{Flow Cytometry and Cell Sorting}

Fleshly-isolated synovial fluid obtained from RA patients who underwent joint surgery was immediately centrifuged, and isolated total cells were washed and filtered through nylon mesh. The cells were incubated 30 minutes at room temperature with Alexa Fluor 647-conjugated anti-human CD14 diluted 50-fold in PBS and FITC-conjugated anti-human CD16 antibodies diluted 10-fold (Biolegend, San Diego, CA). After washing with PBS, CD14 ${ }^{+}$ $\mathrm{CD}_{16}^{-}$cells and $\mathrm{CD} 14^{-} \mathrm{CD} 16^{+}$cells were sorted respectively by FACS-Aria (Becton Dickinson) and used for cell migration assays. Some sorted $\mathrm{CD} 14^{+} \mathrm{CD} 16^{-}$or $\mathrm{CD} 14^{-} \mathrm{CD} 16^{+}$cells were attached to glass slides by Cytospin (Thermo Electron Co., Waltham, MA) and stained by Diff-Quick (Sysmex Inc., Kobe, Japan) according to the manufacturer's protocol. To analyze the integrin expression on $\mathrm{CD} 14^{+} \mathrm{CD} 16^{-}$cells and $\mathrm{CD} 14^{-} \mathrm{CD} 16^{+}$cells, a total of $1 \times 10^{6}$ synovial fluid-derived cells were stained with Alexa Fluor 647-conjugated anti-human CD14 antibody, FITC-conjugated anti-human CD16 antibody, and 10 $\mu \mathrm{g} / \mathrm{ml}$ antibody against each integrin receptor: anti- $\alpha 5 \beta 1$ (HA5, Millipore, Billerica, MA), anti- $\alpha \bigvee \beta 3$ (LM609, Millipore), anti- $\alpha \bigvee \beta 5$ (P1F6, Millipore), anti- $\beta 1$ (6S6, Millipore), anti- $\alpha 4$ (2B4, R\&D Systems, Minneapolis, MN), and anti- $\beta 2$ (R\&D Systems). As negative controls, the cells were reacted with respective isotype-matched control IgG. After washing, $5 \mu \mathrm{g} / \mathrm{ml}$ Cy3-conjugated goat antimouse IgG or donkey anti-goat IgG was incubated with the samples. After washing cells with PBS, the stained cells were analyzed by FACS-Aria using the Flowjo software program.

\section{Cell Migration Assay}

Angptl2-dependent cell migration assays were performed using $\mathrm{CD} 14^{+} \mathrm{CD} 16^{-}$or $\mathrm{CD} 14^{-} \mathrm{CD} 16^{+}$cells as described. ${ }^{18}$ In brief, $\mathrm{CD} 14^{+} \mathrm{CD} 16^{-}$or $\mathrm{CD} 14^{-} \mathrm{CD} 16^{+}$ cells $\left(1 \times 10^{6}\right.$ cells) were inoculated into the upper portion of wells equipped with a 5.0-mm transwell membrane (Corning Inc., Corning, NY). The number of cells that had migrated into the lower part of each well after 4 hours of incubation, as well as the respective concentration of Angpt12, was determined by FACSCalibur (BD Biosciences, Franklin Lakes, NJ).

\section{Statistical Analysis}

All values are given as the means $\pm S D$. Differences in variables were analyzed using Student $t$ test, analysis of variance, and the Mann-Whitney U-test as appropriate, and $P$ values of less than 0.05 were considered to be significant.

\section{Results}

\section{RA Synovial Fluid Shows High Angpt/2 Concentrations}

The Angptl2 concentrations were measured in serum and synovial fluid from RA patients and also from patients with $\mathrm{OA}$, which is a significantly lower grade inflammatory arthritis in comparison with $\mathrm{RA}^{20}$ using the Angptl2 ELISA system $^{18}$ (Figure 1B). Both RA and OA patients underwent knee joint replacement surgery because of the severity of articular destruction and functional decline. All synovial tissues and fluid analyzed in this study were collected from the patients at the time of surgery. General information relevant to both RA and OA patients is presented in Table 1. There was no significant difference in the circulating Angptl2 levels in serum between RA and OA patients, whereas the serum levels of CRP were significantly elevated in RA patients in comparison with those seen in OA patients (Figure 1, A and C). In contrast, Angptl2 concentrations in RA synovial fluid were signifi-
A

$(\mathrm{mg} / \mathrm{dl})$

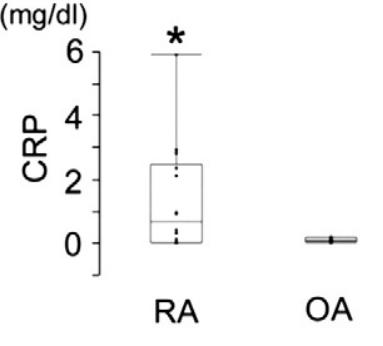

C

(ng/ml)

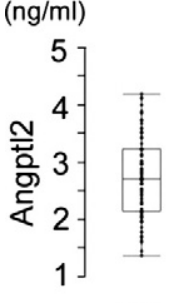

HS

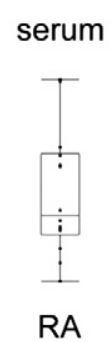

RA

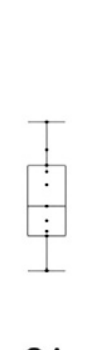

OA
B

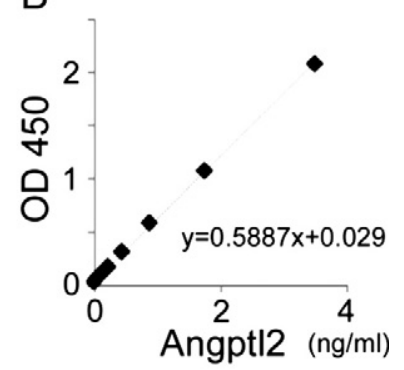

D

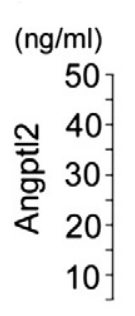

synovial fluid

**

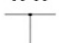

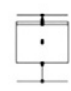

RA

Figure 1. Angptl 2 concentrations in serum and synovial fluid from RA and OA patients. A-D: RA $(n=14)$ and OA $(n=11)$ patients were examined. A: The concentration of serum C-reactive protein (CRP) in RA and OA patients. B: Standard curve obtained in the ELISA system. C: Serum Angpt12 levels in RA and OA patients. D: Synovial fluid Angptl2 levels in RA and OA patients HS indicate the healthy control subjects. ${ }^{*} P<0.05$ and ${ }^{* *} P<0.01$ in comparison with OA patients. 


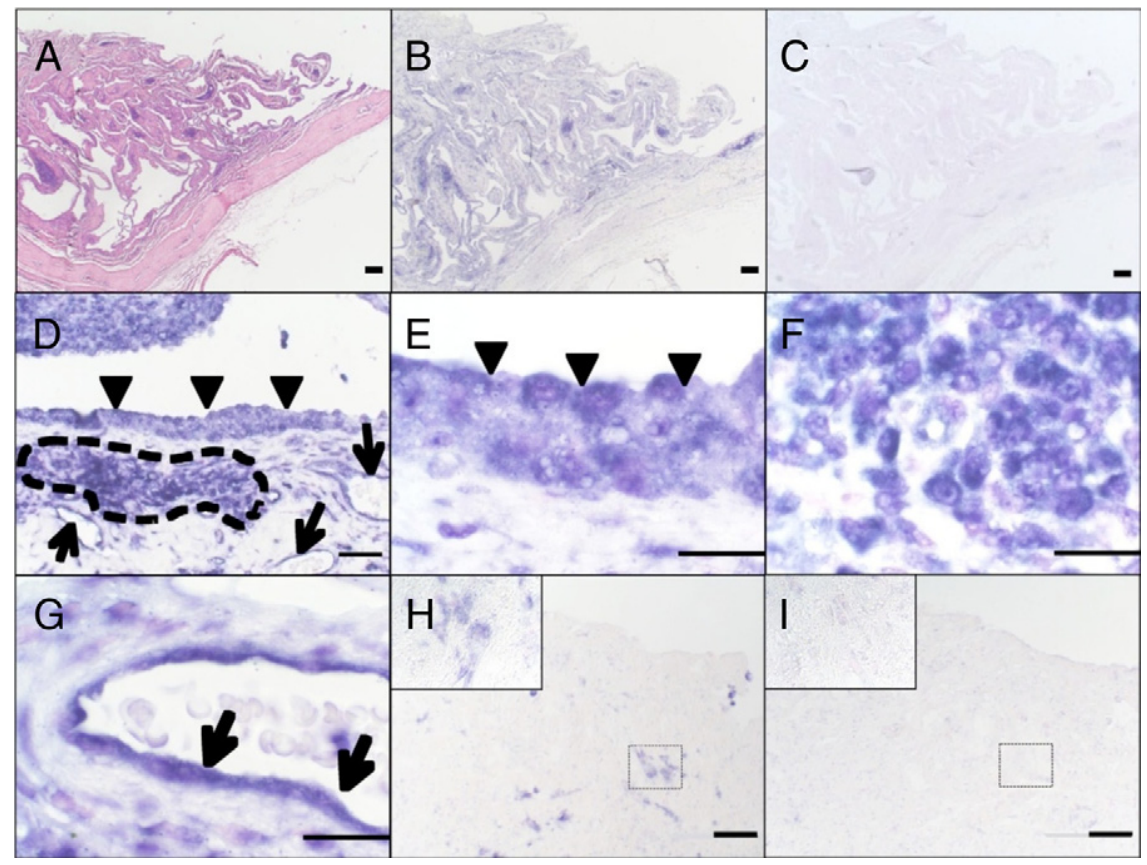

Figure 2. Expression patterns of Angptl2 mRNA in synovium of RA and OA patients as determined by in situ hybridization. A: Lower magnification photograph of the proliferative synovium of an RA patient analyzed using H\&E staining. B-G: Angptl2 mRNA expression in synovium of RA patient evaluated by in situ hybridization. $\mathbf{B}$ and $\mathbf{C}$ : In situ hybridization (B antisense probe; $\mathbf{C}$, sense probe) of serial sections of A. D: Moderate magnification view of proliferative synovium of an RA patient by in situ hybridization. E-G: Higher magnification (in lining cell layer $[\mathbf{E}]$, lymphatic follicles $[\mathbf{F}]$, and endothelial cells $[\mathbf{G}]$ in the RA synovium) of $\mathbf{D}$. $\mathbf{H}$ and I: In situ hybridization findings of the synovium of an OA patient. (H, antisense probe; $\mathbf{I}$ sense probe). Insets indicate higher magnification of each $\mathbf{H}$ and $\mathbf{I}$. The arrowheads indicate lining cell layer in the synovium. The arrows indicate endothelial cells. The area enclosed by dotted lines indicates the lymphatic follicle in the synovium. Data shown are representative expression patterns derived from three independent RA and OA patients, respectively. Scale bars $=200 \mu \mathrm{m}$ in $\mathbf{A}, \mathbf{B}$, and $\mathbf{C}, 50 \mu \mathrm{m}$ in $\mathbf{D}, \mathbf{H}$, and $\mathbf{I}, 20 \mu \mathrm{m}$ in $\mathbf{E}, \mathbf{F}$, and $\mathbf{G}$.

cantly increased in comparison with those seen in OA patients (Figure 1D). These results suggest that Angptl2 might play a role in chronic joint inflammation in $R A$.

\section{Angptl2 mRNA and Protein Are Expressed in the Hyperplastic Lining Cell Layer, Lymphatic Follicles, and Infiltrating Endothelial Cells in the RA Synovium}

H\&E staining revealed hyperplasia of the RA synovium characterized by macrophage-like and fibroblast-like synoviocytes and infiltrating endothelial cells (Figure 2A). The expression of Angptl2 mRNA in the RA synovium was analyzed by in situ hybridization. Anti-sense probes detected Angptl2 mRNA expression in the RA synovium, whereas the sense control probe did not (Figure 2, B and C). Notably, Angptl2 mRNA was abundantly expressed in the hyperplastic lining cell layer (arrowheads in Figure 2, $\mathrm{D}$ and $\mathrm{E}$ ), the lymphatic follicle (framed by dashed lines in Figure 2, D and F), and in endothelial cells (arrows in Figure 2, D and G). In contrast, lower levels of Angptl2 mRNA were observed in synovium from $\mathrm{OA}$ patients, which exhibited a delicate intimal lining (Figure 2, $\mathrm{H}$ and I).

Next, Angptl2 protein expression was examined by immunohistochemistry. All anti-Angptl2 antibodies used in this study recognized specifically human Angptl2 protein, but not Angiopoietin-1 and -2 or other members of Angptl family (data not shown). The hyperplastic RA synovium highly expressed Angptl2 protein (Figure 3, A-C), as observed with the in situ hybridization results. Angptl2 protein was also abundantly expressed in the hyperplastic lining cell layer (arrowheads in Figure 3, D and E), the lymphatic follicles (framed by dashed lines in Figure 3, D and $F$ ), and endothelial cells (arrow in Figure 3, D and G). In contrast, lower Angptl2 protein levels were detected in the synovium from OA patients (Figure 3, $\mathrm{H}$ and I).

\section{Angptl2 Protein Is Expressed in Fibroblast-Like and Macrophage-Like Synoviocytes in the RA Synovium}

Double immunofluorescent staining of the RA synovium was performed to identify which cells produce Angptl2 using antibodies against Angptl2 and markers of specific cell lineages followed by confocal microscopy analysis. In the hyperplastic lining cell layer, vimentin-, synoviolin-, and CD68-expressing cells coexpressed Angptl2 (Figure 4A). In the lymphatic follicle, vimentin-, synoviolin-, and Mac2-expressing cells, but not CD3- or CD20-expressing cells, coexpressed Angptl2 (Figure 4B). Taken together these findings indicate that fibroblast-like and macrophage-like synoviocytes, but not B and T lymphocytes, produce Angptl2 in the RA synovium. Next, the expression of other members of the Angptl family and angiopoietins in the RA synovium was examined. Notably, the expression of Angptl2 mRNA in RA synovial tissues was significantly higher than those of any other Angptls and angiopoietin-1 and -2 (Figure 5A), suggesting important roles of Angptl2 in RA pathogenesis. The secretion of Angptl2 by RA synoviocytes was also investigated. An in vitro culture analysis of fibroblast-like synoviocytes revealed that Angptl2 concentrations in the culture medium after initiating the culture were significantly increased at the time of passing in all cases (Figure 5B). These findings indicate that the RA synovium secretes Angptl2.

\section{Angpt/2 Increases Chemotactic Activity of RA Synovial Fluid-Derived Monocytes}

Angptl2 promotes chemotactic activities of primary human monocytes from peripheral circulation and THP-1 human monocyte cells through integrins $\alpha 4$ and/or $\beta 2 .^{18}$ Therefore, RA synovium-derived Angptl2 may contribute 


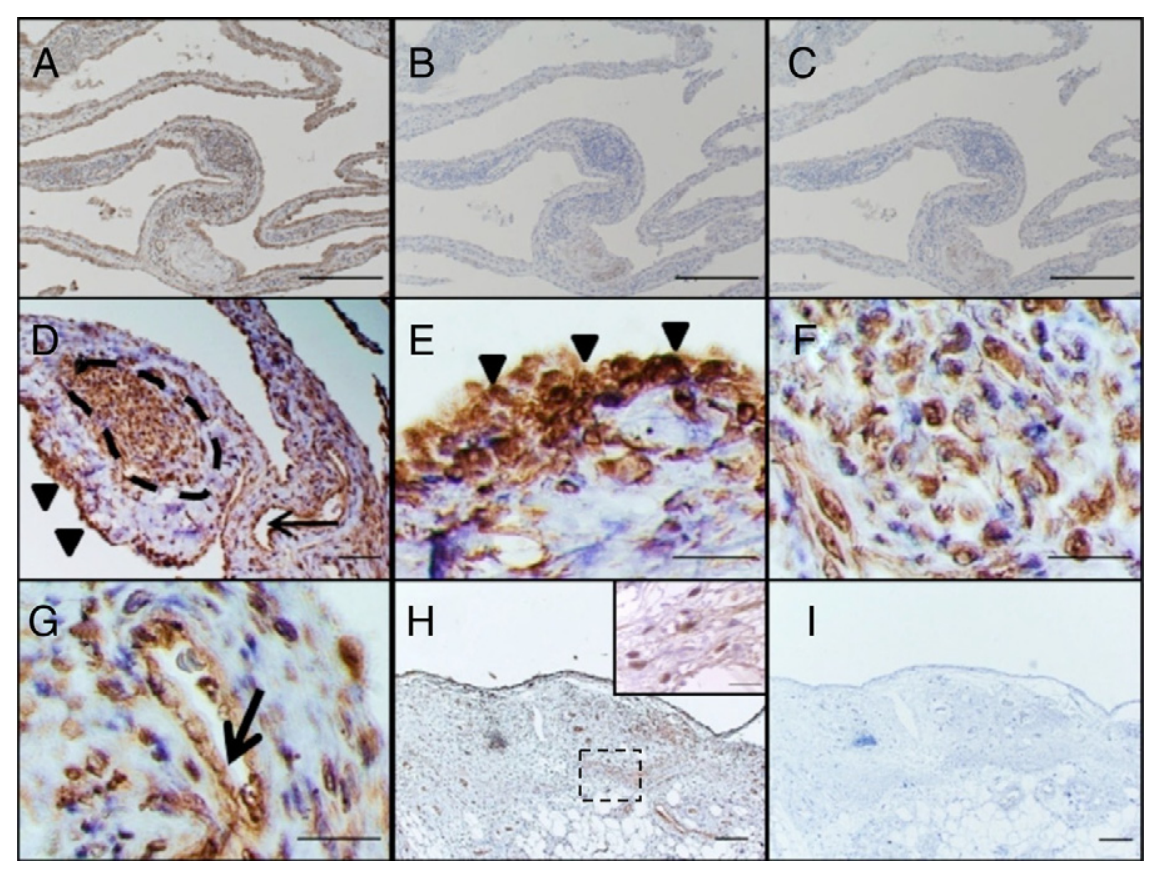

Figure 3. Angptl2 immunohistochemistry in the synovium of an RA patient. A-G: Immunohistochemistry for Angptl2 in the RA synovium. A-C: Lower magnification photograph of Angptl2 protein expression ( $\mathbf{A}$, anti-Angptl2 antibody; $\mathbf{B}$, isotype IgG control; C, second antibody only) in proliferative synovium of an RA patient. D-G: Higher magnification (in lining cell layer [E], lymphatic follicles $[\mathbf{F}]$, and endothelial cells $[\mathbf{G}]$ in the RA synovium) of $\mathbf{D}$. The arrowheads indicate lining cell layer. The arrows indicate endothelial cells. The area enclosed by dotted lines indicates lymphatic follicle. Data shown are representative expression patterns derived from 14 independent RA patients. $\mathbf{H}$ and $\mathbf{I}$ : Lower magnification photograph of Angptl2 protein expression (H, anti-Angptl2 antibody; $\mathbf{I}$, isotype $\operatorname{IgG}$ control) in proliferative synovium of an OA patient. Inset in $\mathbf{H}$ shows higher magnification of H. Data shown are representative expression patterns derived from 11 OA patients. Scale bars $=200 \mu \mathrm{m}$ in $\mathbf{A}, \mathbf{B}$, and $\mathbf{C}, 50 \mu \mathrm{m}$ in $\mathbf{D}, \mathbf{H}$, and $\mathbf{I}, 20 \mu \mathrm{m}$ in $\mathbf{E}, \mathbf{F}$, and $\mathbf{G}$.

to inflammation within RA joints by increasing monocyte infiltration into the synovial fluid. CD $14^{+} \mathrm{CD} 16^{-}$monocytes and $\mathrm{CD}_{14}^{-} \mathrm{CD}^{-} 6^{+}$neutrophils were isolated from RA synovial fluid by FACS (Figure 6, A-C), and the isolated cells were confirmed to be monocytes and neutrophils by histology (Figure 6D). On average, the percentage of $\mathrm{CD} 14^{+} \mathrm{CD} 16^{-}$monocytes in comparison with total cells from RA synovial fluid was about 28\% (Figure 6E). FACS analysis revealed that RA synovial fluid-derived CD14 ${ }^{+} \mathrm{CD}_{16}^{-}$monocytes expressed integrins $\alpha 4, \beta 2$, $\beta 1$, and $\alpha 5 \beta 1$, whereas CD14 ${ }^{-} \mathrm{CD}_{16}{ }^{+}$neutrophils expressed only integrin $\beta 2$ at low levels (Figure 6F). Angptl2 promoted chemotactic activities of primary human monocytes from RA synovial fluid in a dose-dependent manner (Figures 6G), whereas few such effects were observed in neutrophils after Angptl2 treatment (data not shown). The difference in the number of accumulated monocytes in synovial tissue between RA and OA was examined because synovial tissue is a source of Angptl2 in RA joint and its expression is significantly higher than in $O A$. Mac2-positive monocytes/macrophages in RA synovial tissue were markedly increased in comparison with $\mathrm{OA}$ (Figure $6 \mathrm{H}$ ). In addition, an increased number of $\mathrm{CD} 31^{+}$ endothelial cells in RA synovial tissue was observed in

A

Angpt12

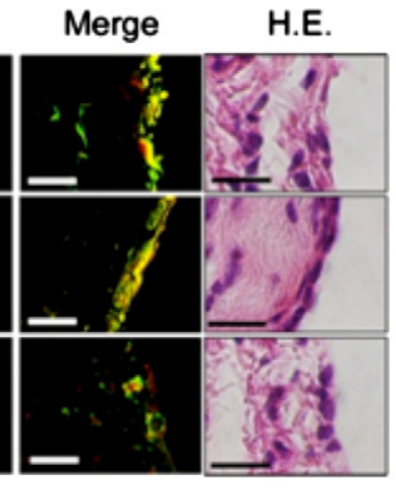

B vimentin synoviolin Mac2
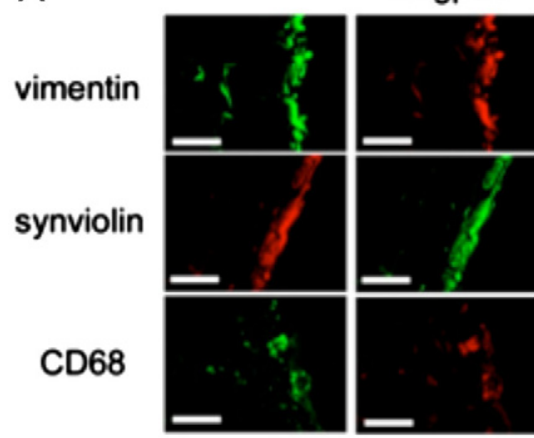

\begin{abstract}
$\mathrm{CD} 3$
\end{abstract}
CD20

IgG

PBS

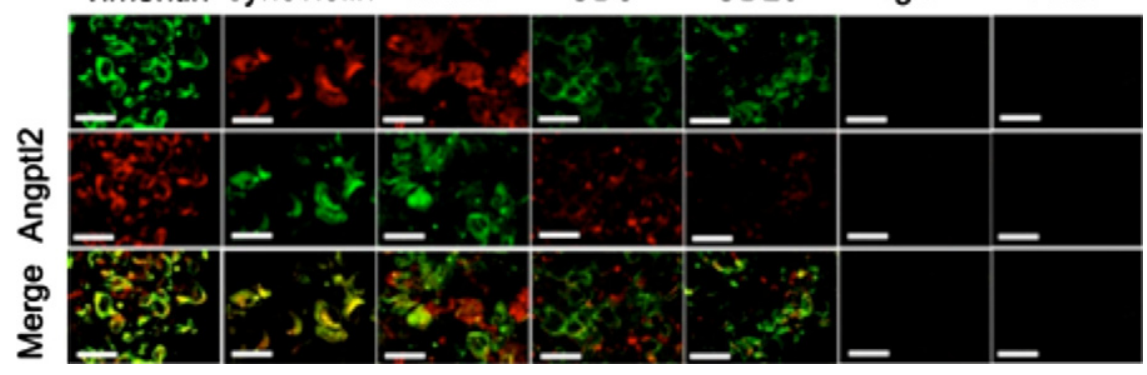

Figure 4. Double immunofluoresence staining for Angptl 2 and cellular lineage markers. A: The coexpression of Angptl2 with vimentin, synoviolin, or CD68 in the lining cell layer with from a patient with RA. Angptl2 is expressed in fibroblast-like synoviocytes (vimentin ${ }^{+}$cells and synoviolin $^{+}$cells) and macrophage-like synoviocytes $\left(\mathrm{CD} 68^{+}\right.$cells). B: The coexpression in the lymphatic follicle from a patient with RA of Angptl2 with vimentin, synoviolin, MAC2, CD3, or CD20. Angptl2 is also expressed in fibroblastlike synoviocytes (vimentin ${ }^{+}$and synoviolin ${ }^{+}$ cells) and macrophage-like synoviocytes $\left(\mathrm{MAC}^{+}\right.$ cells), but not in $\mathrm{T}\left(\mathrm{CD}^{+}\right)$or $\mathrm{B}\left(\mathrm{CD} 20^{+}\right)$cells Representative expression patterns derived from three independent RA patients are shown. IgG indicates isotype IgG control; PBS, second antibody only. Scale bars $=20 \mu \mathrm{m}$ in all panels. 
A

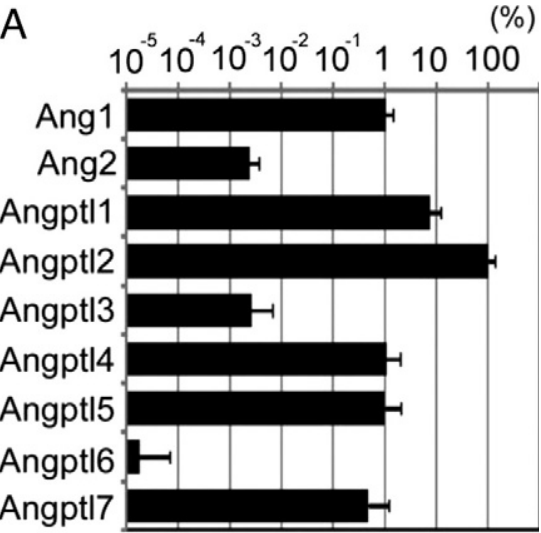

B

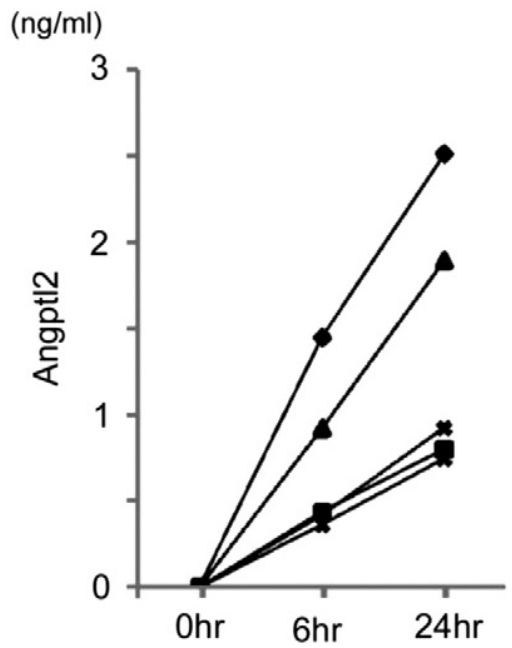

Figure 5. Expression and secretion of Angptl2 in primary RA synovial fibroblasts. A: Comparison of the relative expression levels of Angptl family and angiopoietin-1 (Ang1) and -2 (Ang2) in RA synovial tissue $(n=8)$ estimated with a Quantitative RT-PCR analysis. Closed columns indicate relative mRNA levels normalized to $\beta$-actin mRNA levels. The data of Angptl2 was set to $100 \%$. Columns represent the means \pm SD. B: Concentrations of cultured synovial tissues-derived Angptl2 protein secreted into the medium were determined by ELISA at 0 hours (medium before starting culture), 6 hours, and 24 hours after starting the culture $(n=5)$.

comparison with OA (Figure 6I). Angptl2 might function in inflammatory pathogenesis of RA through increasing chemotactic activities not only for monocytes/macrophages but also for endothelial cells in the RA synovium because Angptl2 could promotes chemotactic activity in a variety of endothelial cells. ${ }^{18,22}$

\section{Serum Angpt/2 Concentrations Are Correlated with RA Disease Activity}

Therefore, Angptl2 would be a strong candidate as proinflammatory factor in RA synovial tissues. Therefore, this study examined whether serum Angptl2 levels correlate with RA disease activity. Because the general disease activity of RA is commonly evaluated by using the DAS28-ESR score or DAS28-CRP score, serum Angptl2 levels in outpatients $(n=206)$ were compared with RA disease activity evaluated by DAS28 scores. The serum Angptl2 levels positively correlated with both DAS28-ESR and DAS28-CRP scores (Figure 7A). In addition, serum Angptl2 levels were significantly elevated in patients with increased RA disease activity characterized by DAS28CRP active/DAS28-ESR active or DAS28-CRP remission/ DAS28-ESR active (Figure 7B). There was no difference in the serum Angptl2 levels between the healthy controls and RA patients without RA disease activity characterized by DAS28-CRP remission/DAS28-ESR remission. In addition, no patient demonstrated DAS28-CRP active/ DAS28-ESR remission.

\section{Angptl2 Concentrations Correlate with Angpt/4 Levels in RA Synovial Fluid}

Although the expression analysis indicated that the expression levels of Angptl4 in RA synovial tissues were about $1 / 100$ of those of Angptl2 (Figure 5A), several recent reports suggested a contribution of Angptl4 in RA pathogenesis. ${ }^{23,24}$ To investigate whether Angptl4 would function in RA pathogenesis, the levels of Angptl4 in both serum and synovial fluid were also measured by ELISA for specifically for the full-length form of Angptl4 (Figure 8A). Synovial fluid Angptl4 levels were significantly elevated in comparison with OA, whereas there was no difference in the serum Angptl4 levels between RA and OA (Figure 8B). Interestingly, the synovial fluid Angptl2 levels positively correlated with the synovial fluid Angptl4 levels, thus suggesting a functional relationship between them in RA pathogenesis (Figure 8C).

\section{Discussion}

Angptl2 is a chronic inflammatory mediator. ${ }^{18}$ This is the first report that activated synoviocytes-derived Angptl2 might play an important role in RA pathogenesis through promoting synovial inflammation.

RA is a chronic inflammatory disease characterized by symmetrical polyarticular synovitis and joint destruction. ${ }^{1}$ The RA synovial membrane contains many cell types, including endothelial cells, monocytes/macrophages, lymphocytes, and osteoclasts as activated infiltrating cells, and synoviocytes as activated resident cells. These cells play important roles in inflammation and joint destruction in RA. ${ }^{1,2}$ Angptl2 promotes migration of endothelial cells through the integrin $\alpha 5 \beta 1$ receptor. ${ }^{18}$ In addition, Angptl2 binds to primary human circulating monocytes and human THP-1 monocytic cells through integrin $\alpha 4$ or $\beta 2$ receptors ${ }^{18}$ and can induce their migration. The current study found that CD $14^{+} \mathrm{CD} 16^{-}$monocytes in RA synovial fluid also express integrin $\alpha 4$ and $\beta 2$ receptors and that Angptl2 promotes chemotaxis in these cells. These findings suggested that the Angptl2-induced chemotactic activity of monocytes would be dependent on Angptl2-integrin signaling like the mechanisms underlying Angptl2-induced chemotactic activity of endothelial cells. Monocytes/macrophages, which are major sources of proinflammatory cytokines, play an important role in chronic inflammation of RA. ${ }^{4,25}$ These findings suggest an important role for RA synovium-derived Angptl2 in 
B

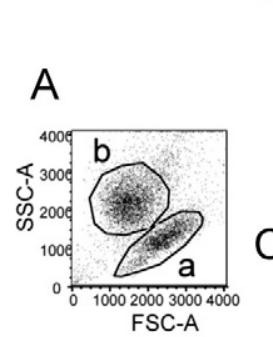

C
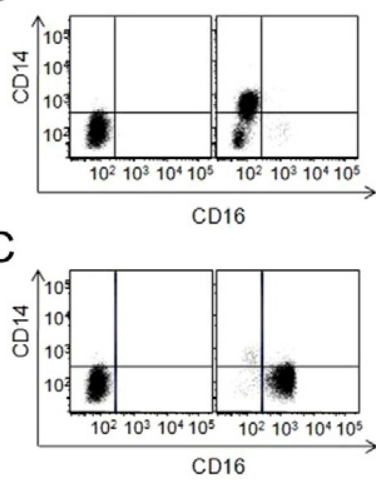

D

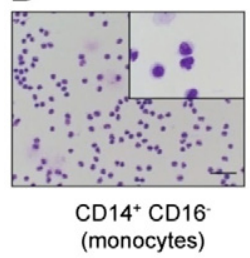

$\mathrm{E}$

요 80

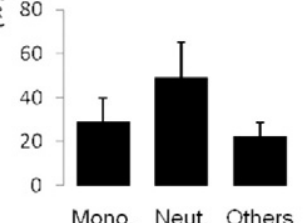

Mono. Neut Others

$\mathrm{F}$

$\mathrm{CD} 14^{+} \mathrm{CD} 16^{-}$ (monocytes)

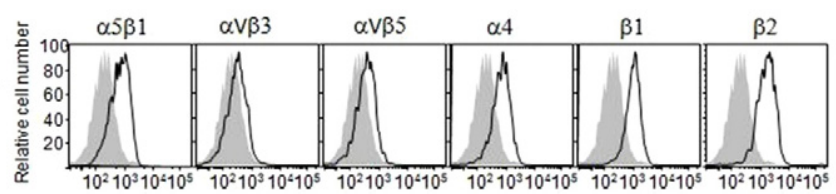

CD16 ${ }^{+}$CD14
(neutrophils)

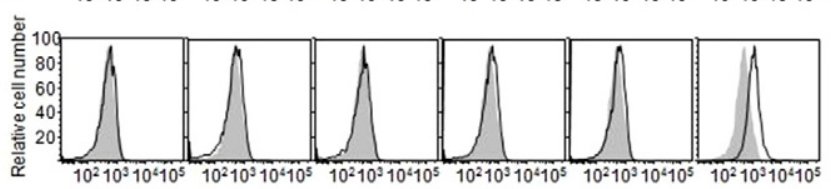

G

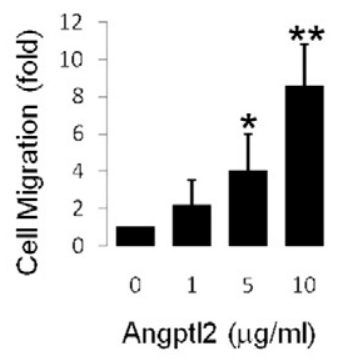

$\mathrm{H}$

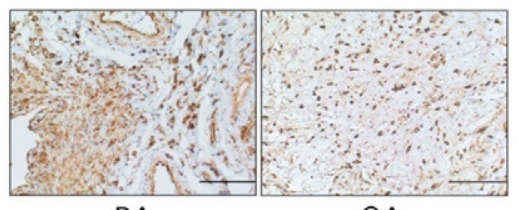

RA
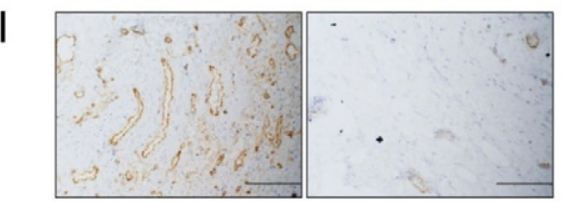

RA

$\mathrm{OA}$

Figure 6. Expression pattern of integrins in synovial fluid-derived monocytes and the Angptl2-induced monocyte migration activity. A: Total cells in RA synovial fluid were sorted for differences in size (forward scatter, FSC) and density (side scatter, SSC). This analysis identified two populations, indicated as $\mathbf{a}$ and $\mathbf{b}$. B FACS analysis of RA synovial fluid-derived cells in population a of A. C: FACS analysis of cells from population $\mathbf{b}$ of $\mathbf{A}$. D: $\mathrm{CD} 14^{+} \mathrm{CD} 16^{-}$(left) and $\mathrm{CD}^{-} 4^{-} \mathrm{CD} 16^{+}$(right) cells were sorted from RA synovial fluid and stained with DiffQuick. Insets show high magnification of each panel. Scale bars $=50 \mu \mathrm{m}$. E: Percentages of each cell type in RA synovial fluid based on three independent experiments. Error bars indicate + SD F: A FACS analysis of CD14 ${ }^{+} \mathrm{CD} 16^{-}$ monocytes (upper) and $\mathrm{CD} 14^{-} \mathrm{CD} 16^{+}$neutrophils (lower) for integrin expression patterns. Shown are representative expression patterns using anti-integrin antibodies (black lines) or isotype-matched IgG (filled gray tracings) derived from three independent patients. G: A migration assay for synovial fluid-derived $\mathrm{CD} 14^{+} \mathrm{CD} 16^{-}$ monocytes. H: Immunohistochemistry for Mac-2 in the RA and OA synovium. I: Immunohistochemistry for $\mathrm{CD} 31$ in the RA and OA synovium. Error bars indicate + SD. ${ }^{*} P<0.05,{ }^{* * *} P<0.01$, versus normalized migration rate in the absence of Angptl2. recruitment of monocytes/macrophages, which are increased in the synovium and synovial fluid in RA.

The synovium is normally a relatively acellular structure with a delicate intimal lining. ${ }^{1}$ In contrast, the RA synovium is greatly expanded, and many infiltrating cells, including not only inflammatory hematopoietic lineage cells but also vascular endothelial cells, exist in the RA synovium. ${ }^{1,2}$ Angiogenesis is known to feed the growing synovium, ${ }^{26}$ as observed in neoplastic disease. Increased vascularization was observed in the RA synovium (Figure 6I). Vascular endothelial growth factor plays a pivotal role in angiogenesis during expansion of the RA synovium. ${ }^{26,27}$ Angptl2 also induces angiogenesis 22,28 by increasing the chemotactic but not proliferative activity of endothelial cells through activating Rac1 in endothelial cells via integrin $\alpha 5 \beta 1,{ }^{18}$ suggesting a role for Angptl2 in the expanding synovium through promoting angiogenesis coordinated with other angiogenic factors. Furthermore, Angptl2 stimulates nuclear translocation of $\mathrm{NF}-\kappa \mathrm{B}$ through integrin $\alpha 5 \beta 1$, resulting in increases in $\mathrm{NF}-\kappa \mathrm{B}$-dependent inflammatory gene expression in endothelial cells and chronic vascular inflammation. ${ }^{18} \mathrm{An}$ - gptl2 signaling is thus an important player in chronic inflammation in RA, because vascular inflammation is also commonly observed in chronic inflammatory pathogenesis ${ }^{26,29}$ and NF- $\kappa$ B is activated in the synovium of RA patients. ${ }^{1,30,31}$ Suppression of cytokine-induced inflammation by several antirheumatic drugs could be important strategies in the treatment of RA through suppressing inflammatory cellular infiltration and angiogenesis in the RA joints. ${ }^{2,25}$ In this regard, inhibiting Angptl2 function would be a good strategy to suppress the proinflammatory cytokine production by inhibiting the recruitment of monocytes/macrophages.

One measure of the clinical characteristics of RA is articular destruction, as well as synovitis. ${ }^{1}$ Activated osteoclasts function in the process of articular destruction. ${ }^{32,33}$ Angptl2 affects a different cell type through distinct integrins. In this regard, it is of interest to determine whether Angptl2 contributes to articular destruction by activating osteoclasts, because osteoclasts express some integrins, and integrin signaling can activate osteoclasts. ${ }^{34}$ Furthermore, integrins, such as $\alpha 5 \beta 1$, are highly expressed in not only infiltrated monocytes/mac- 
A

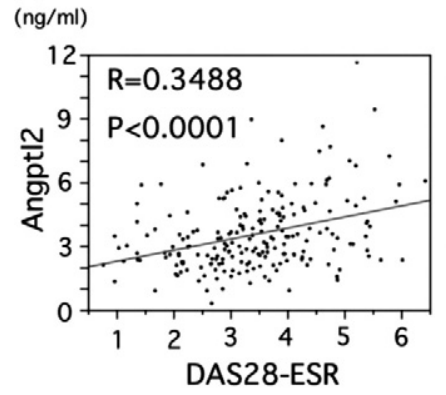

A

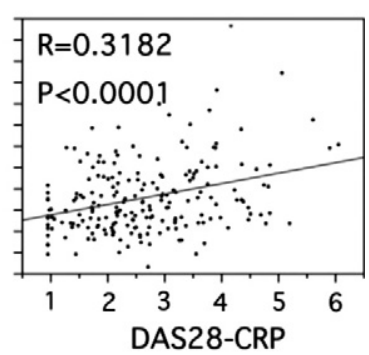

B

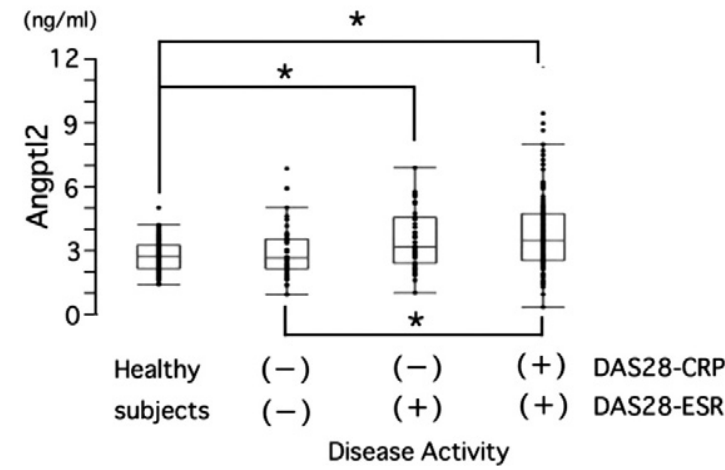

Figure 7. The correlation between serum Angptl2 levels and RA disease activity. A: Correlation of the serum Angptl2 level with DAS28-ESR, DAS28CRP in RA outpatients $(n=206)$. B: Serum Angptl2 levels in healthy volunteers (healthy control subjects, $n=84$ ) and in nonactive RA patients characterized by DAS28-CRP remission/DAS28-ESR remission (DAS28$\mathrm{CRP}(-) / \mathrm{DAS} 28-\operatorname{ESR}(-), n=46)$ patients showing increased RA disease activity characterized by DAS28-CRP remission/DAS28-ESR active (DAS28$\mathrm{CRP}(-) / \mathrm{DAS} 28-\mathrm{ESR}(+), n=44)$ or DAS28-CRP active/DAS28-ESR active (DAS28-CRP(+)/DAS28-ESR(+), $n=116$ ). Horizontal bars represent the 10 th and 90 th percentile range, and boxes indicate the 25 th to 75 th percentile range. The horizontal line in each box corresponds to the median. ${ }^{*} P<$ 0.05 versus healthy control subjects.

rophages but also in RA synovial fibroblasts (also known as fibroblast-like synoviocytes), ${ }^{35-38}$ which are key cellular players in RA pathogenesis. Synovial fibroblasts express some matrix metalloproteinase, which results in Rac1 activation and NF- $\kappa \mathrm{B}$ regulation. ${ }^{39-41}$ In addition, articular chondrocytes express MMPs through $\alpha 5 \beta 1$ integrin signaling. ${ }^{42-44}$ These findings suggest that the intra-articular high concentrations of Angptl2 affect many cell types in RA joint tissues, resulting in pathological changes of RA. Further investigation is required to identify the role of Angptl2 in RA pathogenesis. Angptl4, the other member of Angptl family, is highly expressed in the early phase of collagen-induced arthritis, ${ }^{45}$ whereas Angptl2 highly expressed in the later phase of collageninduced arthritis. These findings are consistent with the current findings that clinical samples analyzed in this study were all obtained from late stage of RA, and Angptl4 mRNA expression in RA synovial tissues were about 1/100 of those of Angptl2 (Figure 5A), suggesting that Angptl4 expression may be more elevated in early stage of RA synovial tissues. Angptl4 promotes MMP-1 and MMP-3 expression in primary chondrocytes from patients with RA. ${ }^{24}$ This study found a positive correlation in between the concentrations of Angptl2 and Angptl4 in the synovial fluid, suggesting that they might act competitively or compensatively in RA pathogenesis.

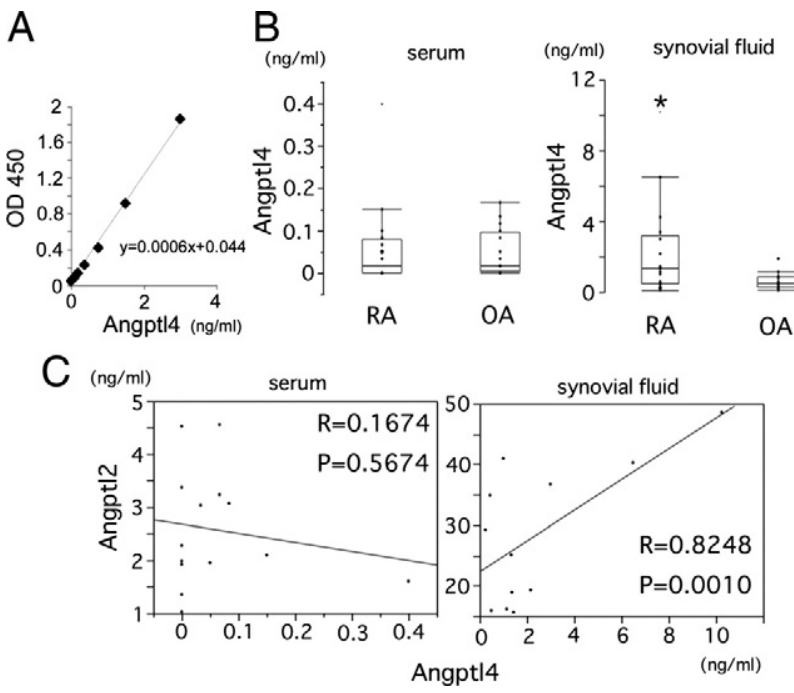

Figure 8. Correlation of full-length form of Angptl4 levels in RA synovial fluid with Angptl2 in RA synovial fluid. A: Standard curve obtained in the ELISA system for Angptl4. B: Angptl2 concentrations in serum (left graph) and synovial fluid (right graph) derived from RA $(n=14)$ and OA $(n=11)$ patients. C: No correlation was observed between the serum Angptl2 levels and the serum Angptl4 levels (left), but a positive correlation was seen between the synovial fluid Angptl2 levels and the synovial fluid Angptl4 levels (right).

This study revealed that the activated RA synovium abundantly expresses Angptl2 mRNA and protein and that synovial cells secrete Angptl2. These findings raise the question of the mechanisms underlying the upregulation of Angptl2 expression in RA synovium. The Angptl2 expression is increased by hypoxia, malnutrition, and endoplasmic reticulum stress in obese adipose tissues. ${ }^{18}$ Various miroenvironmental changes observed in the RA joint, such as inflammation and hypoxia, could also promote endoplasmic reticulum stress. ${ }^{46-49}$ Therefore, Angptl2 production in the synovium might be increased by such environmental stimuli in RA, resulting in increased synovial fluid concentrations of Angptl2 in RA patients in comparison with OA patients. Interestingly, serum Angptl2 levels in RA patients are also correlated with diseases activity, suggesting a role of Angptl2 in advancing RA inflammatory pathogenesis and a possibility of serum Angptl2 levels as a clinical biomarker of RA disease activity. It is necessary to determine whether serum Angptl2 levels reflects the Angptl2 expression levels in synovial tissues and the fluid of RA joints, because there was only a trend association between Angptl2 concentrations in serum and synovial fluid in this study. This may be attributable to the small number $(n=14)$ of RA inpatients who provided specimens for estimating the correlation in this study. The general activities of most of RA patients analyzed in this study were well-controlled, and patients in this study actually showed lower CRP levels in comparison with those reported elsewhere. ${ }^{8}$ Therefore, further investigation of a large number of RA patients including uncontrolled RA disease states is required to identify whether synovial fluid Angptl2 concentrations affects serum Angptl2 concentration and to reveal the measured circulating Angptl2 levels would therefore be useful as a clinical biomarker for the RA disease activity. 
$\mathrm{OA}$ is characterized by degeneration of articular cartilage and changes in periarticular and subchondral bone. ${ }^{50}$ Recent studies of OA have provided new insights into how chronic lower grade activation of proinflammatory pathways contributes to OA pathogenesis. ${ }^{50-52}$ The current study found lower concentrations of Angptl2 in OA synovial fluid relative to those of RA and that the cells expressing Angptl2 at lower levels were scattered in the OA synovium. Interestingly, both RA synovial fluid and OA synovial fluid contain amount of fibronectin fragments, which act as ligands for $\alpha 5 \beta 1$ integrins $^{43,44}$ as well as Angptls. Integrin signaling stimulated by fibronectin fragments in human articular chondrocytes is associated with production and release of MMP- $13,{ }^{42}$ which is a potent mediator of cartilage matrix degradation for $\mathrm{OA}$ pathogenesis. ${ }^{53}$ These findings suggest that intraarticular Angptl2 might induce production of MMPs by stimulating integrin signaling, including $\alpha 5 \beta 1$ integrin, and contribute matrix degradation in pathogenesis of OA. It would be interesting to investigate the role of Angptl2 in $\mathrm{OA}$ in addition to RA.

In summary, this study provides evidence that Angptl2 is abundantly expressed and secreted in the RA synovium and suggests that Angptl2 plays a role in inflammation of the RA synovium via inflammatory vascular remodeling and recruitment of macrophages into RA joints. Recent reports suggesting a possible role of other member of the Angptl family, such as Angptl ${ }^{23,24}$ and Angptl5 ${ }^{17}$ in pathogenesis of arthritis, including RA, have accumulated. Further investigation to identify the roles of Angptl family in pathogenesis of RA might therefore open the door to the development of new therapeutic approaches for RA.

\section{Acknowledgments}

We thank Rieko Shindo, Yasuko Indo, and Otoha Takahashi for their valuable experimental assistance.

\section{References}

1. Firestein GS: Evolving concepts of rheumatoid arthritis. Nature 2003, 423:356-361

2. Brennan FM, Mclnnes IB: Evidence that cytokines play a role in rheumatoid arthritis. J Clin Invest 2008, 118:3537-3545

3. Palmer DG: The anatomy of the rheumatoid lesion. Br Med Bull 1995, 51:286-295

4. Makrygiannakis $D$, Revu S, Neregard $P$, af Klint E, Snir O, Grundtman C, Catrina Al: Monocytes are essential for inhibition of synovial T-cell glucocorticoid-mediated apoptosis in rheumatoid arthritis. Arthritis Res Ther 2008, 10:R147

5. Nakano S, Mishiro T, Takahara S, Yokoi H, Hamada D, Yukata K, Takata Y, Goto T, Egawa H, Yasuoka S, Furouchi H, Hirasaka K, Nikawa T, Yasui N: Distinct expression of mast cell tryptase and protease activated receptor-2 in synovia of rheumatoid arthritis and osteoarthritis. Clin Rheumatol 2007, 26:1284-1292

6. Tran CN, Lundy SK, White PT, Endres JL, Motyl CD, Gupta R, Wilke CM, Shelden EA, Chung KC, Urquhart AG, Fox DA: Molecular interactions between $T$ cells and fibroblast-like synoviocytes: role of membrane tumor necrosis factor-alpha on cytokine-activated T cells. Am J Pathol 2007, 171:1588-1598

7. Petrovic-Rackov L, Pejnovic N: Clinical significance of IL-18. IL-15,
IL-12 and TNF-alpha measurement in rheumatoid arthritis. Clin Rheumatol 2006, 25:448-452

8. Lebre MC, Jongbloed SL, Tas SW, Smeets TJ, Mclnnes IB, Tak PP Rheumatoid arthritis synovium contains two subsets of CD83-DCLAMP-dendritic cells with distinct cytokine profiles. Am J Pathol 2008, 172:940-950

9. Yamanaka H, Tanaka Y, Sekiguchi N, Inoue E, Saito K, Kameda H, likuni N, Nawata M, Amano K, Shinozaki M, Takeuchi T: Retrospective clinical study on the notable efficacy and related factors of infliximab therapy in a rheumatoid arthritis management group in Japan (RECONFIRM). Mod Rheumatol 2007, 17:28-32

10. Abramson SB, Amin A: Blocking the effects of IL-1 in rheumatoid arthritis protects bone and cartilage. Rheumatology (Oxford) 2002, 41:972-980

11. Dayer JM, Bresnihan B: Targeting interleukin-1 in the treatment of rheumatoid arthritis. Arthritis Rheum 2002, 46:574-578

12. Finnegan A, Doodes PD: Pathways for interleukin-1-driven arthritis. Arthritis Rheum 2008, 58:3283-3285

13. Schett G, Stach C, Zwerina J, Voll R, Manger B: How antirheumatic drugs protect joints from damage in rheumatoid arthritis. Arthritis Rheum 2008, 58:2936-2948

14. Takagi N, Mihara M, Moriya Y, Nishimoto N, Yoshizaki K, Kishimoto T, Takeda Y, Ohsugi Y: Blockage of interleukin-6 receptor ameliorates joint disease in murine collagen-induced arthritis. Arthritis Rheum 1998, 41:2117-2121

15. Sano H, Arai K, Murai T, Fujisawa J, Kondo N, Netsu T, Hanyu T, Saeki $\mathrm{T}$, Ito $\mathrm{T}$, Endo $\mathrm{N}$ : Tight control is important in patients with rheumatoid arthritis treated with an anti-tumor necrosis factor biological agent: prospective study of 91 cases who used a biological agent for more than 1 year. Mod Rheumatol 2009, 19:390-394

16. Oike $Y$, Yasunaga $K$, Suda $T$ : Angiopoietin-related/angiopoietin-like proteins regulate angiogenesis. Int $\mathrm{J}$ Hematol 2004, 80:21-28

17. Hato $T$, Tabata $M$, Oike $Y$ : The role of angiopoietin-like proteins in angiogenesis and metabolism. Trends Cardiovasc Med 2008, 18:6-14

18. Tabata M, Kadomatsu T, Fukuhara S, Miyata K, Ito $\mathrm{Y}$, Endo M, Urano T, Zhu HJ, Tsukano H, Tazume H, Kaikita K, Miyashita K, Iwawaki T, Shimabukuro M, Sakaguchi K, Ito T, Nakagata N, Yamada T, Katagiri H, Kasuga M, Ando Y, Ogawa H, Mochizuki N, Itoh H, Suda T, Oike $\mathrm{Y}$ : Angiopoietin-like protein 2 promotes chronic adipose tissue inflammation and obesity-related systemic insulin resistance. Cell Metabolism 2009, 10:178-188

19. Arnett FC, Edworthy SM, Bloch DA, McShane DJ, Fries JF, Cooper NS, Healey LA, Kaplan SR, Liang MH, Luthra HS: The American Rheumatism Association 1987 revised criteria for the classification of rheumatoid arthritis. Arthritis Rheum 1988, 31:315-324

20. Altman R, Asch E, Bloch D, Bole G, Borenstein D, Brandt K, Christy W, Cooke TD, Greenwald R, Hochberg M: Development of criteria for the classification and reporting of osteoarthritis. Classification of osteoarthritis of the knee Diagnostic and Therapeutic Criteria Committee of the American Rheumatism Association. Arthritis Rheum 1986, 29:1039-1049

21. Yang X, Wang J, Liu C, Grizzle WE, Yu S, Zhang S, Barnes S, Koopman WJ, Mountz JD, Kimberly RP, Zhang HG: Cleavage of p53-vimentin complex enhances tumor necrosis factor-related apoptosis-inducing ligand-mediated apoptosis of rheumatoid arthritis synovial fibroblasts. Am J Pathol 2005, 167:705-719

22. Kubota $Y$, Oike $Y$, Satoh S, Tabata $Y$, Niikura $Y$, Morisada T, Akao M, Urano T, Ito $\mathrm{Y}$, Miyamoto T, Nagai N, Koh GY, Watanabe S, Suda T: Cooperative interaction of Angiopoietin-like proteins 1 and 2 in zebrafish vascular development, Proc Natl Acad Sci USA 2005, 102:13502-13507

23. Hermann LM, Pinkerton M, Jennings K, Yang L, Grom A, Sowders D, Kersten S, Witte DP, Hirsch R, Thornton S: Angiopoietin-like-4 is a potential angiogenic mediator in arthritis. Clin Immunol 2005, 115:93-101

24. Murata M, Yudo K, Nakamura H, Chiba J, Okamoto K, Suematsu N, Nishioka K, Beppu M, Inoue K, Kato T, Masuko K: Hypoxia upregulates the expression of angiopoietin-like-4 in human articular chondrocytes: role of angiopoietin-like-4 in the expression of matrix metalloproteinases and cartilage degradation. J Orthop Res 2009, 27:50-57

25. Burmester GR, Stuhlmuller B, Keyszer G, Kinne RW: Mononuclear phagocytes and rheumatoid synovitis. Mastermind or workhorse in arthritis? Arthritis Rheum 1997, 40:5-18

26. Paleolog EM: The vasculature in rheumatoid arthritis: cause or consequence? Int J Exp Pathol 2009, 90:249-261

27. Sekimoto T, Hamada K, Oike Y, Matsuoka T, Matsumoto M, Chosa E, 
Suda T, Tajima N, Yamamura K: Effect of direct angiogenesis inhibition in rheumatoid arthritis using a soluble vascular endothelial growth factor receptor 1 chimeric protein. J Rheumatol 2002, 29:240-245

28. Kim I, Moon SO, Koh KN, Kim H, Uhm CS, Kwak HJ, Kim NG, Koh GY: Molecular cloning, expression, and characterization of angiopoietinrelated protein: angiopoietin-related protein induces endothelial cell sprouting. J Biol Chem 1999, 274:26523-26528

29. Szekanecz Z, Koch AE: Vascular involvement in rheumatic diseases: 'vascular rheumatology.' Arthritis Res Ther 2008, 10:224

30. Han Z, Boyle DL, Manning AM, Firestein GS: AP-1 and NF-kappaB regulation in rheumatoid arthritis and murine collagen-induced arthritis. Autoimmunity 1998, 28:197-208

31. Ospelt C, Brentano F, Jungel A, Rengel Y, Kolling C, Michel BA, Gay RE, Gay S: Expression, regulation, and signaling of the patternrecognition receptor nucleotide-binding oligomerization domain 2 in rheumatoid arthritis synovial fibroblasts. Arthritis Rheum 2009, 60:355-363

32. Gendron S, Boisvert M, Chetoui N, Aoudjit F: Alpha1beta1 integrin and interleukin-7 receptor up-regulate the expression of RANKL in human $\mathrm{T}$ cells and enhance their osteoclastogenic function. Immunology 2008, 125:359-369

33. Shahrara S, Castro-Rueda HP, Haines GK, Koch AE: Differential expression of the FAK family kinases in rheumatoid arthritis and osteoarthritis synovial tissues. Arthritis Res Ther 2007, 9:R112

34. Teitelbaum SL: Osteoclasts: what do they do and how do they do it? Am J Pathol 2007, 170:427-435

35. Hanyuda M, Kasama T, Isozaki T, Matsunawa MM, Yajima N, Miyaoka $\mathrm{H}$, Uchida H, Kameoka Y, Ide H, Adachi M: Activated leucocytes express and secrete macrophage inflammatory protein-1alpha upon interaction with synovial fibroblasts of rheumatoid arthritis via a beta2-integrin/ICAM-1 mechanism. Rheumatology (Oxford) 2003, 42:1390-1397

36. Kiener HP, Lee DM, Agarwal SK, Brenner MB: Cadherin-11 induces rheumatoid arthritis fibroblast-like synoviocytes to form lining layers in vitro. Am J Pathol 2006, 168:1486-1499

37. Kitagawa A, Miura Y, Saura R, Mitani M, Ishikawa H, Hashiramoto A, Yoshiya S, Shiozawa S, Kurosaka M: Anchorage on fibronectin via VLA-5 (alpha5beta1 integrin) protects rheumatoid synovial cells from Fas-induced apoptosis. Ann Rheum Dis 2006, 65:721-727

38. Zeisel MB, Druet VA, Wachsmann D, Sibilia J: MMP-3 expression and release by rheumatoid arthritis fibroblast-like synoviocytes induced with a bacterial ligand of integrin alpha5beta1. Arthritis Res Ther 2005, 7:R118-R126

39. Kheradmand F, Werner E, Tremble P, Symons M, Werb Z: Role of Rac1 and oxygen radicals in collagenase-1 expression induced by cell shape change. Science 1998, 280:898-902
40. Huhtala P, Humphries MJ, McCarthy JB, Tremble PM, Werb Z, Damsky $\mathrm{CH}$ : Cooperative signaling by alpha 5 beta 1 and alpha 4 beta 1 integrins regulates metalloproteinase gene expression in fibroblasts adhering to fibronectin. J Cell Biol 1995, 129:867-879

41. Werb Z, Tremble PM, Behrendtsen O, Crowley E, Damsky CH: Signa transduction through the fibronectin receptor induces collagenase and stromelysin gene expression. J Cell Biol 1989, 109:877-889

42. Forsyth CB, Pulai J, Loeser RF: Fibronectin fragments and blocking antibodies to alpha2beta1 and alpha5beta1 integrins stimulate mitogen-activated protein kinase signaling and increase collagenase 3 (matrix metalloproteinase 13) production by human articular chondrocytes. Arthritis Rheum 2002, 46:2368-2376

43. Yasuda T: Cartilage destruction by matrix degradation products. Mod Rheumatol 2006, 16:197-205

44. Guo D, Ding L, Homandberg GA: Telopeptides of type II collagen upregulate proteinases and damage cartilage but are less effective than highly active fibronectin fragments. Inflamm Res 2009, 58:161-169

45. Thornton S, Sowders D, Aronow B, Witte DP, Brunner HI, Giannini EH, Hirsch R: DNA microarray analysis reveals novel gene expression profiles in collagen-induced arthritis. Clin Immunol 2002, 105:155-168

46. Murdoch C, Muthana M, Lewis CE: Hypoxia regulates macrophage functions in inflammation. J Immunol 2005, 175:6257-6263

47. Yamasaki S, Yagishita N, Tsuchimochi K, Kato Y, Sasaki T, Amano T, Beppu M, Aoki H, Nakamura H, Nishioka K, Nakajima T: Resistance to endoplasmic reticulum stress is an acquired cellular characteristic of rheumatoid synovial cells. Int J Mol Med 2006, 18:113-117

48. Gao B, Lee SM, Chen A, Zhang J, Zhang DD, Kannan K, Ortmann RA, Fang D: Synoviolin promotes IRE1 ubiquitination and degradation in synovial fibroblasts from mice with collagen-induced arthritis. EMBO Rep 2008, 9:480-485

49. Yamasaki S, Yagishita N, Tsuchimochi K, Nishioka K, Nakajima T: Rheumatoid arthritis as a hyper-endoplasmic-reticulum-associated degradation disease. Arthritis Res Ther 2005, 7:181-186

50. Goldring MB, Goldring SR: Osteoarthritis. J Cell Physiol 2007, 213:626-634

51. Guilak F, Fermor B, Keefe FJ, Kraus VB, Olson SA, Pisetsky DS, Setton LA, Weinberg JB: The role of biomechanics and inflammation in cartilage injury and repair. Clin Orthop Relat Res 2004, 17-26

52. Hamerman D: The biology of osteoarthritis. N Engl J Med 1989 , 320:1322-1330

53. Takaishi H, Kimura T, Dalal S, Okada Y, D'Armiento J: Joint diseases and matrix metalloproteinases: a role for MMP-13. Curr Pharm Biotechnol 2008, 9:47-54 